\title{
Resource bricolage and growth of product and market scope in social enterprises
}

Corresponding Author: Dr. Misagh Tasavori

Essex Business School, University of Essex,

Elmer Approach, Southend on Sea, Essex, SS1 1LW, United Kingdom

$$
\text { T+44(0)1702328399 }
$$$$
\mathrm{F}+44(0) 1702328385
$$

Email: Tasavori@essex.ac.uk

\author{
Dr. Caleb Kwong \\ Essex Business School, University of Essex, \\ Elmer Approach, Southend on Sea, Essex, SS1 1LW, United Kingdom \\ $\mathrm{T}+44(0) 1702328200$ \\ $\mathrm{F}+44(0) 1702328385$ \\ Email: ckwong@essex.ac.uk
}

Dr. Sarika Pruthi

School of Global Innovation \& Leadership, Lucas College \& Graduate School of Business,

San Jose State University (SJSU)

Business Tower 950, One Washington Square

San José, CA 95192-0066, USA

Tel/ Fax: +1 (408) 924654

Email: Sarika.pruthi@sjsu.edu 


\title{
Resource bricolage and growth of product and market scope in social enterprises
}

\begin{abstract}
This research aims to understand how resource bricolage strategy plays a role in the growth of social enterprises in terms of their product and market. Based on interviews with nine social enterprises, our exploratory finding suggests that social enterprises often employ both internal and network resources in the process of making do. We further explore the relationship between the form of resource utilisation and the nature and scope of activities that the social enterprises embark upon, and find that only those relying on both internal and network bricolage are able to expand into new markets utilising newly developed products. We also find that social enterprises relying on only internal resources can reach the same point through incremental improvisation, by first moving towards either product extension or market expansion, before then embarking on the other. This research contributes to the social entrepreneurship literature by enhancing our understanding of the relationship between resource bricolage strategy and growth of social enterprises through product/ market scope in a penurious environment. The findings of this research also have implications for social enterprise managers and policy makers in utilising their resources and responding to environmental opportunities and challenges.
\end{abstract}

Keywords: bricolage, improvisation, resource constraints, market expansion, product extension, social enterprise 


\section{Introduction}

Social enterprises (SEs) offer products, services and support to communities and markets previously neglected by the free market due to limited financial returns (Leadbeater 1997; Thompson 2002). Unlike commercial ventures, SEs pursue a social mission to create social value rather than maximise profit (Dees, Anderson, and Wei-Skillern 2004; Paton 2003; Austin, Stevenson, and Wei-Skillern 2006). As they are reluctant to raise prices in order to increase revenue (Lasprogata and Cotton 2003), SEs face a penurious environment where mobilisation of resources can be difficult (Mair and Marti 2006) and better utilisation of what is available at-hand is imperative. Such an approach is closely related to the concept of entrepreneurial bricolage, which focuses on the transformation and reconfiguration of resources at-hand, thereby maximising their potential in generating value (Baker and Nelson 2005). While bricolage has increasingly been recognised in the entrepreneurship and social entrepreneurship literatures as a viable strategy to tackle resource constraints in penurious contexts (Desa 2012; Di Domenico, Haugh, and Tracey 2010), current research on bricolage does not address how firms, specifically SEs, employ bricolage to extend their product and market scope.

We refer to 'product scope' as offering an existing or new product, and 'market scope' as targeting a product or service to existing or new customers (Ansoff 1965). Expansion of their product and market is important for SEs as they are eager to create a better world by addressing more urgent social needs, continuously exploring social gaps and submerging themselves in ideas to address these gaps (Di Domenico, Haugh, and Tracey 2010). Considering a tight funding environment with growing competition for donors and grants (Bugg-Levine, Kogut, and Kulatilaka 2012) and SEs' reluctance to charge their customers premium prices (Bugg-Levine, Kogut, and Kulatilaka 2012), an understanding of SEs' use of bricolage, as a common resource mobilisation strategy (Di Domenico, Haugh, and Tracey 2010), in the extension of their product and market scope may provide insights into a new approach to how social gaps can be filled and scaled (Perrini, Vurro, and Costanzo 2010).

Many authors [most notably Di Domenico, Haugh, and Tracey (2010)] view improvisation as inherent to bricolage. Improvisation highlights the emerging and interdependent relationship between business decisions within a changing context. The improvisation perspective suggests that each bricolage outcome should be seen as part of a 
process, or 'a means to an end' rather than 'the end itself' (Weick 1989). Such a longitudinal view for employing bricolage and developing product and market scope is particularly important in the examination of SEs that, due to their lack of profit emphasis in comparison to commercial ventures, may be steered into a very different business development path in the use of bricolage and improvisation. Therefore, we address the following research questions in this research: How do SEs use bricolage to extend their product and market scope? What is the role of improvisation in the process of extending product and market scope over time?

We advance understanding of bricolage and growth in SEs in two ways. First, previous studies have extensively explored questions of how organisations deploy bricolage as part of their resource mobilisation strategies (Baker, Miner, and Eesley 2003; Baker and Nelson 2005) as well as how bricolage can be linked to growth in terms of economic and innovation outcomes (Baker and Nelson 2005; Senyard et al. 2014; Garud and Karnøe 2003; Ferneley and Bell 2006; Halme, Lindeman, and Linna 2012). However, the relationship of bricolage and growth in terms of product and market scope remains a 'black box' (Sirmon, Hitt, and Ireland 2007; Hunt, Boal, and Sorenson 1990; Boxall, Ang, and Bartram 2011), which we argue, can be 'unlocked' through specifically exploring how SEs utilise different forms of bricolage to expand product and market scope. In particular, we explore the role of two forms of bricolage, internal and external (network), in growth of product and market scope in SEs (Baker, Miner, and Eesley 2003). Whilst prior research has made such a distinction, little is known about how different forms of bricolage enable or hinder growth of SEs.

Second, we draw on the improvisation literature to offer a more emerging and longitudinal view of product and market development based on bricolage. Most existing studies on bricolage focus on a single, defining 'turning point' end product, with a particular line of business within the organisation (Duymedjian and Rüling 2010). In alluding to product and market expansion as an emerging 'make do' process that is fluid and dynamic in nature, our study enriches understanding of how the continued use of bricolage may enable SEs to evolve and create new social value despite facing persistent financial constraints.

The structure of the rest of the paper is as follows. First, we present a review of the literature. The research methodology is explained next, followed by the findings and a discussion of these findings, respectively. We conclude with the implications of our findings for theory, policy and practice. 


\section{Literature review}

\subsection{Bricolage and improvisation}

Bricolage offers a theoretical foundation for the ways in which the predispositions of resources that an organisation possesses at a particular point in time can be employed in shaping its future expansion strategies (Miner, Bassoff, and Moorman 2001; Baker, Miner, and Eesley 2003). The term 'bricolage' was first coined by Levi-Strauss $(1967,17)$ as "making do with whatever is at-hand", which involves the use of resources-at-hand, such as physical artefacts, skills or ideas, that are accumulated on the principle that 'they may always come in handy', rather than acquired in response to demands of a specific application for which they have proven capabilities (Baker and Nelson 2005; Desa and Basu 2013; Lanzara 1999). Bricolage implies a bias towards action involving the deployment and integration of resources in novel ways rather than conforming to norms and standard practices originally intended for these resources (Jones, Macpherson, and Jayawarna 2014; Baker and Nelson 2005). Therefore, in contrast to the traditional planned perspective where resources are being sourced and utilised in accordance with a blueprint (Dacin, Dacin, and Tracey 2011; Smith and Blundel 2014; Cunha and Kamoche 2001), bricolage is unplanned and its outcome often offers a degree of serendipity in its ability to generate growth (Cunha and Kamoche 2001; Desa and Basu 2013).

Two types of bricolage are identified in the entrepreneurship literature: internal bricolage and external (network) bricolage. Internal bricolage refers to employing at-hand resources that exist inside the organisation, whereas network bricolage refers to the utilisation of resources residing within its pre-existing personal and professional networks (Baker, Miner, and Eesley 2003). Network bricolage enables access to a much broader variety of 'resources-at-hand', and is particularly relevant to SEs operating within resource-poor communities (Dacin, Dacin, and Matear 2010). Unlike commercial ventures, SEs do not mobilise resources in order to develop competitive barriers (Dacin, Dacin, and Matear 2010). Instead, they view their markets as ripe for friendships that they can use to improve social value creation, increase the number of customers they reach, lower cost of inputs, and turn competitors into collaborators (Kickul and Lyons 2012). Therefore, they may be more likely to use their resources in a co-operative fashion, using persuasive tactics to acquire resources and implement growth strategies. 
Another concept related to bricolage is improvisation. The improvisational nature of bricolage highlights design and execution processes as simultaneous, rather than a priori, sequential and meticulously planned (Di Domenico, Haugh, and Tracey 2010). Improvisation further highlights the emerging and interdependent relationship between business decisions within a changing context, with a number of authors metaphorically comparing the concept to the adaptive executions in jazz performance, or improvised comedy and theatre (Meyer, Frost, and Weick 1998; Lewin 1998; Hatch 1999; Zack 2000; Vera and Crossan 2004; Cunha and Kamoche 2001). However, the direction of the relationship between bricolage and improvisation is debated in the literature (Moorman and Miner 1998). Whereas some studies (e.g., Miner, Bassoff, and Moorman 2001) suggest that improvisation is a precursor to bricolage, others (e.g., Baker and Nelson 2005) argue that bricolage creates a forum in which organisational capacities and behaviours including improvisation, creativity, social skills and combinative capabilities come into play and have a substantial impact on firm outcomes.

The concept of improvisation offers further clarity to the longitudinal development of businesses (Weick 1993a, b). With each new business activity being developed, organisations continually develop new resources and skills that can be used for further improvisations (Weick 1993b). This also suggests that the bricolage outcome of one particular activity that an organisation embarks upon may affect subsequent bricolage attempts and, in turn, affect the expansion strategy an organisation may intend for the future.

The emerging nature of improvisation is particularly important in the business development of SEs. Existing literature on SEs points to a gradual developmental path resembling 'drift' as opposed to 'leap' (Jones 2007). Di Domenico, Haugh, and Tracey (2010) suggest that SEs often adopt strategies to 'try things out' by improvising through minor reconfigurations in order to 'appeal to the relevant audience at the relevant time'. This involves experimenting with different solutions to social issues, even when such diversification may involve greater risks of failure than a more single-minded approach. The potential implication is that bricolage may create more far-reaching diversification through a more gradual improvisation process over time. Although studies recognise the uniqueness of social bricolage, an understanding of the role of bricolage in the gradual growth and expansion of SEs is lacking. 


\subsection{Growth in product and market scope}

The above review of the literature implies that one of the key outcomes of resource bricolage is growth. As organisations continue to make do and improvise, the reconfiguration of resources often results in scope adaptations and growth by further penetration into an existing market with the existing product, developing new product lines deviating from their existing range, or moving into new markets with minimal previous involvement.

In this research we classify growth in terms of both product (Robins and Wiersema 1995; Rumelt 1974) and market scope (Goerzen and Beamish 2003; Hitt, Hoskisson, and Kim 1997) to define four strategies: i) offering more of an existing product to an existing market to better penetrate the market ii) taking an existing product to serve a new market (types of customers), iii) developing a new product for an existing market, and iv) developing new products for new customers.

Market penetration is often considered to be most relevant to SEs (Froelich 1999), with 'bricolage-induced inertia' (Senyard et al. 2014), or internal and stakeholder pressures to resist change, creating considerable barriers to SEs' extension of their product and market scope. There has been a long standing fear of mission drift in the social sector where attempts to divert their energy away from their initial recipients would be met with considerable skepticism from various stakeholders (Kickul and Lyons 2012). As a result, there is a pragmatic tendency of SEs to prioritise their core business before pursuing additional lines of business in areas not too far away from their core competencies.

Nevertheless, studies have suggested that inherited limited prospects and low profitability associated with penurious environments often force organisations to expand into unrelated markets (Christensen and Montgomery 1981; Stimpert and Duhaime 1997) or products (Rumelt 1974; Bowman 1982), both being seen as the backbone of growth and development of organisations and industries (Chang and Choi 1988; McDougall and Round 1984; Suzuki 1980; Montgomery and Singh 1984). Market development and offering existing products to new markets can be seen as advantageous as it enables SEs to scale up and serve a larger number of people in need, in doing so expanding their social mandate (Brooks 2009; Kickul and Lyons 2012). Market development often involves replication of common approaches to other geographic locations or targeting new types of customers (Voss, Montoya-Weiss, and Voss 2006). It thus reduces their market vulnerability of focusing on a single market (Hoskisson and Hitt 1990; Delios and Beamish 1999). Development of new 
products and offering new products to existing markets enables SEs to focus their energies and resources on creating more social value for the intended recipients by finding new products to serve them (Voss, Montoya-Weiss, and Voss 2006). Finally, by developing new products and entering new markets, SEs can utilise their resources to create social value for new types of customers and support other rapidly growing social demands (Froelich 1999).

While internal bricolage contributes to growth of SEs, collaboration with the external network enables SEs to engage in more radical innovation and growth (Senyard et al. 2014). As SEs develop interdependent resource relationships with those within their network (Galaskiewicz, Bielefeld, and Dowell 2006), the web of relations in which they are embedded may also influence their growth strategies (Smith and Stevens 2010). Those within the network may take particular interest in specific geographic locations and sectors of involvement, as well as target markets (Kistruck et al. 2013), and may exert influence on the business development paths that SEs may undertake in the long run. This means that whilst SEs may naturally want to adopt an incremental approach to improvisation and avoid potential conflicts with their dual mission (Kickul and Lyons 2012; Perrini, Vurro, and Costanzo 2010), network bricolage may result in them losing autonomy over their expansion path. This may, on the one hand, result in them leaping away from their expansion effort (Jones 2007), or, on the other hand, preserve the status quo at all cost (Perrini, Vurro, and Costanzo 2010).

Targeting the right customers and satisfying their needs is also very important for employees working in SEs. An internal inertia-based resistance to growth may develop among SEs' staff if they feel that pursuit of growth creates uncertainty and risks the quality of service to customers or jeopardises the existing mission of the SEs (Kickul and Lyons 2012). SEs may thus adopt a less radical approach to the improvisation process. A wealth of literature points to the slow and incremental nature (i.e. 'drift' in contrast with 'leap') of product development (Jones 2007), focusing on minor adjustments to existing products rather than dramatic reconfigurations in the social sector.

Based on a review of the literature, the conceptual framework of this research can be summarised as follows (See Figure 1). As demonstrated in Figure 1, SEs engage in bricolage (internal or network) to mobilise resources. After acquiring resources, they embark upon developing product and market scope, which results in growth. As can be seen, while 
improvisation may not occur in all processes of product/service development, some of these processes might be based on improvisation.

*Insert Figure 1 about here*

\section{Methodology}

\subsection{Research design}

In the social entrepreneurship context where few studies have examined the role of resource bricolage in the development of new activities, a qualitative multiple case study design was pursued in this research to extend theory in this context (Tracy 2013; Graebner, Martin, and Roundy 2012) and to generate new theoretical and managerial insights (Yin 2014). Multiple cases permit a replication logic (Yin 2014) and lead to more robust, generalizable theory than a single case (Eisenhardt and Graebner 2007). To carry out this research, nine SEs in the UK were selected and interviewed. This is consistent with Eisenhardt and Graebner (2007), who suggest that the number of cases in qualitative research should be between 4 and 10, as fewer cases limit the possibility of generalisation, and more cases complicate the analysis.

The context of the UK seemed to be highly relevant for the purpose of this research. In recent years SEs have seen a reduction in the amount of public funding (Cabinet Office 2014) as well as an economic downturn which has impacted their access to resources. Despite this, SEs in the UK have proved to be one of the most rapidly expanding sectors in the world (Cabinet Office: Office of the Third Sector 2006).

\subsection{Data collection and analysis}

In this research, the UK government's definition of SE is adopted, which is "a business with primarily social objectives whose surpluses are principally reinvested for that purpose in the business or in the community, rather than being driven by the need to maximise profit for shareholders and owners" (DTI 2003, 6). In the UK, SEs can assume different legal statuses such as charity, credit union, housing association, Company Limited by Guarantee, Industrial and Provident Society or Community Interest Company (GLA Economics 2007, 5). They operate within a variety of industries including care, childcare, ICT, financial services, retail, tourism, the arts, construction, manufacturing and the environment (GLA Economics 2007). As illustrated in Table 1, the selected SEs were from a diverse range of industries which 
made it possible to obtain more information compared to similar cases (Eisenhardt and Graebner 2007).

SEs were selected based on convenience sampling (Saunders, Lewis, and Thornhill 2012). We contacted by email or phone several SEs in the UK that met our definition. We explained the purpose of the research and invited them to participate in our study. In our invitation, we also pointed out that the names of companies or interviewees would not be revealed. After obtaining their consensus and interviewing the initial person, whenever necessary and possible a second interview was arranged to obtain more information. We employed snowball sampling (Bryman 2008) and asked the first interviewee to introduce another person who might be able to answer our questions.

***Insert Table 1 about here***

Both primary and secondary data were used. Primary data were collected from SEs through semi-structured interviews in order to gain access to more unseen information on respondents' experiences and opinions as well as some past events and rare occasions (Saunders, Lewis, and Thornhill 2012; Tracy 2013). An interview guide (King and Horrocks 2010) was developed based on the existing literature which allowed us to pose similar questions to all interviewees (see Appendix 1). The interview guide included general questions about the background and activities of both the interviewee and the SE, and specific questions to recall incidences when the strategy of resource bricolage had been adopted and how it had resulted in the growth of SEs. As bricolage may be too abstract a concept for interviewees to understand, we broke down our questions into parts using more accessible language (see interview guide). Although not all activities constituted bricolage, we considered it a good way to gain rapport and direct their focus towards activities they had undertaken and on the ways resources had been utilised. Once some of the activities had been identified, we then encouraged the interviewees to provide actual examples based on their experience within the SE. Further questions were asked regarding the nature of these activities, as well as different types of resources they utilised in order to make them happen. The discussion focused predominantly on the activities the interviewees had experienced personally, although other activities were sometimes touched upon to provide further context for the discussion. On returning from the fieldwork, the interviewers re-read the transcripts to confirm whether the activities mentioned fulfilled all the criteria of bricolage as stipulated by Baker and Nelson (2005). 
The first round of interviews was carried out between January and March, 2015. After analysing the data from the first interview, further rounds of interviews were arranged with some of the SEs to collect more information and clarify matters. Interviews lasted between 30 to 90 minutes, and were arranged with key personnel at these organisations. The position of interviewees included founder, Chief Executive Officer (CEO), director of fundraising and marketing, store manager, warehouse manager and systems manager. In total, 14 interviews were conducted, details of which are provided in Table 2. As we did not intend to gather an exhaustive list of all bricolage activities that took place within each SE, we focused on activities that the interviewees had most direct experience of and were most comfortable to discuss. As resource bricolage took place at all levels within an organisation, the inclusion of interviewees involved in different operational aspects of SEs provided a more rounded view of how resource bricolage is used by SEs to achieve growth. Interviews were digitally recorded and then transcribed.

\section{$* * *$ Insert Table 2 about here***}

The collected data was analysed by using thematic analysis (Miles and Huberman 1994). Based on the literature review, priori codes (Sinkovics, Elfriede, and Ghauri 2005) were created which included some themes and sub-themes such as bricolage, improvisation, growth (offering existing product to an existing market, offering existing products to new markets, developing a new product for existing market, and developing new products for new markets). After conducting interviews and gathering secondary data for each case, a case story was developed which demonstrated a chronological order of events (Yin 2014). Then, data analysis and coding was carried out for each SE by two of the authors independently and then discussed and agreed among them. After conducting within case analysis, cross-case analysis was carried out to identify patterns emerging from the cases (Miles and Huberman 1994; Ghauri and Gronhaug 2010).

Two methods of triangulation were used: data source and methodological triangulation (Denzin 1989). First, data source triangulation was ensured by collecting data from different respondents (e.g., McGaughey 2007; Gummesson 2003). Second, methodological triangulation was carried out to cross-check the information and collect different perspectives. This involves both the use of interviews and a wide range of secondary data. As suggested by Yin (2014), secondary data can serve to corroborate and augment the data obtained from key informants. For instance, when analysing the data, whenever we found 
some pieces of information were missing we consulted SEs' pamphlets and online archives of local newspapers, as well as their annual financial report through the Charity Commission. The different sources of information enabled us to obtain information that was not discussed or reported in the interviews, and allowed us to further investigate discrepancies found between the different sources in order to increase reliability.

\section{Findings}

\subsection{Bricolage and growth}

SEs in our research employed both internal bricolage and network bricolage to achieve growth. This section outlines how SEs employ these resources, and details their recombination and transformation to make do in a resource-poor environment in order to achieve growth.

\subsubsection{Internal bricolage}

4.1.1.1.Internal bricolage to grow by improving the 'existing product' for the 'existing market'- When faced with resource limitations, the SEs in the sample often put together their existing, unused resources to improve their existing products in order to create more social value for their current type of customers. For example, the interviewee from Homelessness Support pointed out how redundant physical resources created from funding cuts allowed them to improve their existing service provision to their target customers:

9 years ago we had a project... for people who struggled lifting out of poverty and needed a free place to take their children and be safe and give them advice ... when the funding went... we utilized the space that we had as a waiting room and store area $\ldots$ and what it does mean is transforming those resources into something else... (Homelessness Support).

This case illustrates the principle highlighted in Baker and Nelson (2005) that bricoleurs would always consider ways to reconfigure the resource-at-hand in order to ensure that these resources are being utilised. The following Health Research case, on the other hand, illustrates the "resources may always come in handy" principle of bricolage that was highlighted in Baker and Nelson (2005). The SE utilises their shops to collect and sell second-hand furniture in order to generate extra revenue to support their health-related research. Internal bricolage is applied through the systematic collection of broken furniture in 
the hope of using some of the parts for repairing furniture that they may collect in the future. The interviewee pointed out:

Sometimes we do get some stuff that I have used in a different manner...If the cabinet door is missing or broken, or damaged...we have got some spare that we have collected and kept aside so that we can repair it...

Similarly, concerned with her firm's limited human resources and the necessity of keeping the price of her service low for the customers, the CEO of Coaching Service stated that she regularly collected information and statistics that she thought might be relevant to her customers or service without having a specific use in mind at the time of collection. Over time, the information was being used to update the materials to improve the quality of training provided to the existing customers, which helped her to create satisfied customers and increase demand from other universities to offer the same type of product.

\subsubsection{Internal bricolage to grow by offering a 'new product' to the 'existing market'-} Consistent with Di Domenico, Haugh, and Tracey (2010), some of the SEs interviewed in this research felt that they could create social value by reconfiguring the resources they had to develop new products to better serve their target customers. Consultancy Co., for instance, began to offer a new workshop on measuring social impact in SEs, at the time a new concept, through employing the pre-existing knowledge that they accumulated through the consultancy services they provided to individual SEs.

The social mission of Disadvantaged Youth is to enhance the well-being of homeless, abused, poor or unemployed young people who have left home. While their main focus is on offering accommodation, they noticed through the project that their clients struggled due to a lack of the basic skills needed to live alone, and required further support. Therefore by utilising their existing resources, they developed a 12-week course to teach young people about health, hygiene, and safety as well as food preparation.

Coaching Service intended to support the students who had underperformed academically because of stress or other mental health issues. The founder started the service as a one-on-one coaching and counselling service, in the hope of improving students' wellbeing and enabling them to achieve their full potential. Therefore, when she was asked to develop training courses that could be offered to a group of students, she did so by augmenting the contents of her existing coaching and counselling materials to suit a group 
focus. Consistent with Cunha and Kamoche (2001), such change was unplanned, but nevertheless it was their flexibility to adopt and to reconfigure their pre-existing resources that enabled the SE to quickly capture the emerging opportunity.

\subsubsection{Internal bricolage to grow by offering an 'existing product' to the 'new market'-}

Some SEs in our study appreciate that the expansion of their products into new markets generates more social value. Coaching Service, for example, expanded its market from providing training to students to offering training programmes for parents through the modification of materials that the organisation had at hand.

The social mission of Audiology Services is to address their patients' hearing impairments. Therefore, whenever equipment and products become surplus to requirements, they send them to developing countries free of charge to be used by those in need, by doing so entering a new market that did not exist before. Similarly, International Aid donated some of their unwanted books to a recycling company free of charge, thereby creating a positive environmental impact. Homelessness Support provided a local church with food parcels, targeting homeless people outside their usual catchment.

\subsubsection{Network bricolage}

When encountering resource limitations, SEs not only employed their internal resources to make do and expand their social value but also utilised the resources of their network, consistent with Baker, Miner, and Eesley (2003). These networks included individuals, relevant public bodies, and other social as well as commercial organisations. These contacts provided relevant resources to enable making do to occur, as explained below.

\subsubsection{Network bricolage to grow by improving an 'existing product' for the 'existing} market'- Social problems and challenges often encourage SEs to approach their existing network to seek their support in penetrating the market and offering their existing product to the existing market. For example, Health Research works with a charity that sends unemployed volunteers to its retail shops to gain work experience while helping the company to sell more of its products.

SEs also share their knowledge with each other to help reduce costs or improve the quality of their products to serve the unmet needs of their more marginalised customers. For example, both Audiology Services and the Hospice pointed out that they shared best practices about what worked in areas such as treating patients, fundraising activities, and managing 
volunteers. Sometimes they also undertook joint research projects to find out about the latest practices in treating patients. Such bricolage attempt is consistent with Kickul and Lyons (2012), who suggest that SEs often hold a collective, as opposed to competitive, attitude towards other social organisations.

Furthermore, such collaborative mentality also extends to bricolage attempts involving for-profit partners. The respondent at the Hospice stated that when they were constrained with limited resources and did not have the money to improve the experience of their service users, they sometimes approached for-profit companies to tap into their knowledge and expertise through their corporate social responsibilities initiatives:

In my team, I cannot afford to pay training- we do not have a budget for that. What we can do is to go to Rolls Royce- they have an excellent management programmeand ask if I can have 2 places in their management programme. We do a lot of things like that. (The Hospice)

\subsubsection{Network bricolage to grow by offering a 'new product' to the 'existing market'-} Collaboration with others from within the network often enables SEs to enhance their resource base, and encourages them to see how these resources can be best utilised to create new products intended to create additional social value for those they currently serve (Dacin, Dacin, and Tracey 2011). There were a number of cases where organisations extended their product by exchanging pre-existing resources, allowing them to access each other's facilities free of charge, such as gyms (e.g. Disadvantaged Youth) and transport vehicles (e.g. Health Research and Homelessness Support) that would otherwise be unavailable. Disadvantaged Youth, for instance, provided a mental health charity with access to their kitchen, in return referring their clients with noted mental health problems to their specialists.

Homelessness Support worked with a charity specialising in reducing social isolation to organise a book club. The initiative utilised their own premises and books donated to them, as well as the ideas, expertise and experienced convenors from their partners. The collaboration enabled them to come up with a new activity for their respective target groups, thereby helping both parties to achieve their social mission by better serving their markets with minimal additional costs. 
Empower held their annual students' entrepreneurship project competition in conjunction with the annual enterprise educator conference of another social organisation promoting entrepreneurial behaviours in education. The initiative to collaborate provides the respective users of the two organisations with immediate and free access to each other's events, but more importantly, provides interactions between the two user groups. For Empower, the interaction enables their participating students to have immediate access to experienced educators who can provide them with valuable entrepreneurial advice. For their partner organisation, it provided educators who enriched their conference with some valuable case studies of student projects and direct interactions with students from other educational establishments to further understand the nature of the contents of their enterprise education curriculums, and learn their opinions about them.

\subsubsection{Network bricolage to grow by offering an 'existing product' to the 'new market'-} Working with others often broadens the horizons of the SEs in terms of recognising additional social value that can be created through serving a new market that they may not initially have been aware of. For example, with additional support obtained through various partners, including the local government, children's charities and other supporters, the Hospice expanded its market by opening a hospice especially for children, utilising existing competencies as an adult hospice operator. In addition, because of the considerable number of homeless people in the region and the lack of hospice support for this market, the Hospice collaborates with charities serving the homeless population to derive a strategy towards securing financial supports for a hospice for the homeless.

Another example is related to Consultancy Co. which entered China with the help of the British Council who identified the opportunities in China and suggested that Consultancy Co. should bid:

There are a number of local authorities that we've traditionally worked with and whenever they can they have come to us and said, "There's something we'd like you to do." For the last four years we've been working very closely with the British Council; the work in China, Malaysia, Armenia, Morocco has all come through the British Council, so they've come and asked us to bid for work in these places. (Consultancy Co.)

When Consultancy Co. won the bid, it used its existing course materials and modified them to fit the local context. In both cases, additional resources enabled SEs to expand their 
existing services to new markets. Our study adds to Dacin, Dacin, and Matear (2010), who suggest that networks offer SEs valuable resources. We also found that network bricolage could enable SEs to develop further connections and offer them new opportunities to generate social value.

\subsubsection{Network bricolage to grow by offering a 'new product' for the 'new market'-} Through the government's Empty Homes initiative, Homelessness Support, for example, was given a previously derelict hotel and a renovation grant to redevelop it into a transitional supported accommodation for the homeless. During their residence, various forms of support were provided to prepare them for finding suitable mainstream and long-term accommodation. The activity diverged rather radically from their existing business activities, shifting from both their original activity as day support and night shelter providers to transitional accommodation providers, and from their initial market of homeless people to those no longer considered homeless but who required support to move on to long-term accommodation. Despite this divergence, the SE did not reject the opportunity as the new product and new market still helped the firm to reduce social problems. While the newly acquired premises were undoubtedly crucial and without which the project would not have been possible, a number of pre-existing capabilities and resources were equally important. This included their competencies as sheltered accommodation homeless support providers, but also with the provision of furniture, bedsheets and other homeware that was already available through donations to their retail outlets.

In cases when network bricolage allowed SEs to address new social problems, they often embraced the opportunity to do so. International Aid Relief, for instance, worked with partners to develop Fairtrade and ethical product ranges. The joint project required minimal additional competencies from the SEs, and utilised their existing retail outlets and online shop that were previously selling only second hand goods.

Another example of working with other organisations to offer new products for the new market by making do with resources at hand can be found in Coaching Service. It collaborated with a community arts and music charity to develop a workshop on stress management through arts and music. The basis of the workshop was developed from a stress management workshop template that was previously offered to students who were anxious about examinations. Nevertheless, the content was further developed through close collaboration between the two parties to tailor it for those with mental health problems. 


\subsection{Improvisation and growth}

When SEs engaged in bricolage, improvisation was also pursued in order to respond to the opportunities or challenges that emerged over time. This is consistent with Di Domenico, Haugh, and Tracey (2010). While the bricolage section demonstrated the changes in product and market scope at one point in time, the findings of this research suggest that improvisation and growth is not a static, but continuous, process. The changing external and internal specificities mean that SEs need to improvise in order to respond to opportunities or challenges that emerge over time. Therefore, in this section we present details of unplanned changes in market and product scope over a period of time. The remainder of this section highlights improvisational approaches we have identified among the interviewed SEs. From the analysis in the bricolage section, it is apparent that some of the making do responses to changes in opportunities are more transformative (offering a new product to a new market). Other making do attempts appear less radical, as they involve offering either a new product to an existing market or introducing existing products to a new market. Similarly, our findings illustrate that two approaches of 'incremental' and 'radical' can be adopted towards improvisation.

\subsubsection{An incremental approach to improvisation}

There are a number of SEs in our study which, over time, incrementally augmented resources towards new usages. In the case of Coaching Service, bricolage first involved the branching out from coaching to training for the same market (type of customers), before rolling out further training programmes for a new market (parents). Therefore, while each move the SE made amounted to just a small step, after a few rounds of improvisations, the activities, products and services provided by the SEs, as well as the target market, changed from what they first had in mind.

In Consultancy Co., the switch from providing consultancy to training for other nonprofit organisations was followed by the diversification of both the training content as well as their target market. For instance, it started delivering enterprise skills training to unemployed people, which was a new market they had not originally considered. The delivery of training support for non-profit organisations in China, Malaysia, Armenia and Morocco also diverged from its initial plan though proving to be a success for the organisation: 
...when we decided to set up Consultancy Co., in our business plan we had never thought that we would be doing training...within a few weeks of setting up, someone came to us and said, "Can you run a workshop for us?" We said, "Yeah." We'd never done it before, but I didn't tell him that; we said, "Yeah, of course we can." Now about $50 \%$ of our work comes out of running workshops. (Consultancy Co.)

The process of improvisation also involved close collaboration between the SEs and customers to make sure the product suited their needs. For example, when Consultancy Co. was asked to create a toolkit and manual on SE for young students in China, they initially based the training materials on existing manuals. However, they received feedback from customers that it was too complicated for them, and therefore the company had to modify the manual several times. This was emphasised by the CEO of Consultancy Co., as illustrated below:

At the end of the day, we're working for their [customer] benefit not for our benefit; we have to keep thinking of our customer, not the product we' re selling... Even when we have used something five times before, we go to another community and we think “well they must have similar views." Sometimes they don't: we have to work with them, we have to listen to them. (Consultancy Co.)

The interview transcripts suggested a few reasons for the incremental approach to improvisation. The first is due to the limited resources of the SE and uncertainty of success with the new project. Therefore, SEs went through a process of trial and error as opposed to a more drastic shift, which would have jeopardised the effectiveness of the products, services and activities currently offered to their clients. For instance, according to the interviewee from Homelessness Support:

...the basic use of the building hasn't changed but pretty much everything else has. Everything we have planned changed and we have done that as an evolving process and made decisions [accordingly]... We are a client led service...to be responsive to our customers we implemented projects such as Alcoholics Anonymous and Narcotics Anonymous... we didn't know how they were going to work a year ago but we had to put things in place because that helps. (Homelessness Support)

In this case, offering new products to the existing market provided the SE with an opportunity to test the validity of the new products without drastically altering their core competencies, so they could therefore revert to their original position if the new venture was not successful, 
without incurring too many losses. This sentiment was also reflected by Consultancy Co. as indicated by the following quote:

...well, we've occasionally launched into things without a clear mind, for instance, almost ten years ago impact measurement was still not a well-recognised area in SE work. We started offering lots of workshops on a free basis, or half day for $£ 5$, just to try to get people, because we think this is a big issue you need to get to grips with, and we didn't know how it would work out, what would happen... however, people bought tickets and did not turn up... and we had to keep trying to play around with the content and the importance and so, slowly over the years it's becoming more and more important, and now we're able to charge for it. We have done things of that sort, where we have no idea in which direction it's going to end up. (Consultancy Co.)

The second reason for the adoption of a less radical approach was related to the sensitivity of the SEs' clients. We found that SEs dealing with vulnerable health situations, such as palliative care, tended to adopt a cautious approach towards improvisation that appeared to be less likely to result in transformative improvisation. In some of the SEs, for instance the Audiology Services and the Hospice, a cautious stance was generally taken with regard to improvisation, for fear that new initiatives might not adequately serve those who were considered to be most in need within their existing market. While not against making do or improvisation, the Hospice, for example, spoke of the danger of moving too fast with reference to their mobile hospice project (a new product to be offered).

Thirdly, our findings indicate that SEs may be taking a cautious stance towards improvisation for fear that any drastic change may adversely affect their relationship with their stakeholders, particularly when they are financially dependent on the latter. The Managing Director of Audiology Services explained the role of the National Health Service (NHS), its financial backer, in dictating their activities, by imposing stringent internal financial criteria and reporting systems:

We have a very big NHS contract for our area with the local clinical commissioning groups and with the local hospital...for some very specialised stuff; we do what the hospital asks us to do... when we applied for [contract] money, we have mentioned what we want to do with the money and what we want to achieve ... my finance director would be very cross with me [if I implement a different project without considering the resource situation]... (Audiology Service) 
The dependent relationship often resulted in the SEs adopting a more planned, incremental, rather than unplanned and radical approach towards improvisation over time. In the case of Audiology Service, they explained:

We generally set our budget in such a way that we make a small surplus... What we might do, when we set the budget, if we are underspent on one line of business, say hearing aid repair, then we might decide to wire some of that money towards other aspects. So we could do a small project within the same year, but not massive [project]... We have just started doing that ...this year we opened a shop in the middle of the High Street... we did not know the money was to be used for it when we saved it as a surplus, but it became a decision that we needed at the time but not on our business plan $1^{\text {st }}$ April [start of the fiscal year] that year... (Audiology Service)

\subsubsection{A transformative approach to bricolage}

Other cases in our sample illustrated that improvisation can offer more radical changes. Compared to incremental improvisation where SEs develop a new market or product incrementally, transformative improvisation involves not only targeting a new market but also a new product at the same time. As previously reported, there were a number of cases where such an approach towards bricolage occurred. Cross-case analysis revealed that strong external resource network and supportive collaborators were a common denominator, and appeared to be crucial to the successful development of transformative improvisation. While the previous sub-section illustrates that bricolage with external resources does not guarantee transformative action, cross-case analysis revealed that none of the transformative initiatives was developed by employing only internal resources. From our cases, we noted a number of reasons for this. One reason may be that transformative improvisation is resource demanding. Joined-up resources enable SEs to work with a larger resources endowment, be it physical, human or financial, in turn enhancing the financial viability of the larger, more transformational initiatives, and becoming more ambitious. The heavy resource requirement involved in transformative action may explain the difficulty in doing so simply by relying on pre-existing resources and competencies. A manager from Homelessness Support spoke about the significant changes required when they took on a transformative project providing housing accommodation, a new service to a new market, making it hard for those without additional resources: 
Becoming a housing provider is very different from being a charity or a night shelter.

We have different requirements [between night shelter and supported accommodation]... and there are different regulations around that... in addition there are needs for furniture and bedding... a surplus [through network partnership] enabled us to take risks. (Homelessness Support)

In addition, the presence of a network allowed sharing risks and uncertainties, and providing SEs a buffer in case of failure. Coaching Service's venturing from offering student coaching to training for teaching was made possible due to the financial support offered by a school within their existing network. This enabled the team to focus their effort on designing a tailor-made training curriculum for the specific new audience, without having to worry about the potential negative financial consequence.

The second reason for the pursuit of transformative improvisation (offering a new product to a new market) in the presence of network bricolage is the need to cater to the different social mission of both partners. For instance, Coaching Service participated in an art and music programme that was organised by another SE specialising in art therapy for those with mental health issues. From the partner's point of view, Coaching Service's experience in stress management was crucial for the success of the therapy programme. From Coaching Service's point of view, not only did they have limited experience in art and music therapies, the fact that target users included people from all walks of life, not just students, was also something novel to them. Thus the partnership enabled Coaching Service to participate in a co-created and transformative social venture that served the social mission of its partner. It should be mentioned that Coaching Service started this transformative improvisation (extension of its social mission to new product and new market) only after obtaining the support of its key financial providers.

Our study also found that these transformative ventures could often encourage SEs to learn about the needs of the new market and co-create additional social value. Consultancy Co. had an experience whereby someone from their network, a local council, had some financial resource (funding) availability for the purpose of promoting sustainability, but had no idea what to do with it. Consultancy Co. arranged a meeting with the partner and their users, and extensively discussed with them their needs and requirements in helping them to attain sustainability. Utilising Consultancy Co.'s extensive experience in conducting training, they ended up with a tailored training product to serve a new user group comprised of the 
users of their partner. This is a perfect example of social outcome co-creation, not only between SEs and their partner, but also with users, made possible through network bricolage.

In addition, our findings suggest that SEs that are more likely to adopt a transformative approach are more entrepreneurial and willing to take more risks in their approach. For instance, instead of cost-cutting and downsizing as would be expected from an organisation during economic retrenchment, Homelessness Support uses its savings to further develop its pre-existing capacity in the hope of increasing their creditability amongst large financial backers and generating funds for activities that are connected to their core competencies:

We wanted to create a workforce that was a risk...we have used our reserves to employ more people to be more effective [create more social value] then we are more appealing to funding providers. We can go to a funding provider who's putting out a tender for a contract and say we are established, we've got a team of 10 people working to support people and we've been effective because we have put in the resources of our own. (Homelessness Support)

These large financial backers, as we have seen in the previous point, increase the chance of transformative improvisation being implemented.

\section{Discussion}

Our findings corroborate prior research (e.g., Seelos and Mair 2005; Neck, Brush, and Allen 2009; Rangan et al. 2007; Lasprogata and Cotton 2003) in showing bricolage as a resource mobilisation strategy among SEs owing to their desire to offer affordable products to their beneficiaries. Akin to commercial ventures, SEs use both internal and external bricolage (Baker, Miner, and Eesley 2003). We found instances where SEs make do solely with internal bricolage, as well as those where they combine internal and network resources in their reconfiguration efforts. The use of external resources is also in line with the entrepreneurship literature elucidating the role of networks (Anderson and Jack 2002; Andreosso-O'Callaghan and Lenihan 2008; Batjargal 2010; Chabaud et al. 2012; Lechner and Dowling 2003), as well as studies on the role of network bricolage in the bricolage process (Baker, Miner, and Eesley 2003; Garud and Karnøe 2003). 
A novel finding of our study is that SEs are heterogeneous in the way they engage in bricolage to diversify the product and market scope of their activities. To answer the first research question, How do SEs use bricolage to extend their product and market scope?, we summarise the different approaches that SEs deploy to expand their market and product scope into four strategic alternatives: : market penetration, incremental expansion of market, incremental extension of product and radical transformation of both product and market, respectively. Figure 2 provides a graphical representation. We found many instances of incremental extension of product and incremental expansion of market in our sample, suggesting that the deployment of bricolage, both the internal and network varieties can contribute to the diversification of product and market scope in SEs. In contrast, few SEs engaged in radical transformation involving both product and market diversification. External resources appeared to be crucial for implementing radical transformation, as none of the activities thus classified relied solely on internal, pre-existing resources and competencies. Prior literature has long suggested the role of radical diversification in innovation and growth (Ettlie, Bridges, and O'Keefe 1984). External bricolage could potentially enable SEs to overcome their resource constraints in pursuing a more radical and innovative growth path, as suggested by studies such as Senyard et al. (2014). However, these attempts to radically transform are often more risky, entailing a higher chance of failure, with Sarasvathy (2001) once describing those engaging in radical transformation to be in the 'suicide quadrant'. Insights from our cases show that financial support from collaborators reduces some of the risks associated with failure, and enables SEs to be more entrepreneurial and innovative in moving away from their initial offerings. Furthermore, our findings show that the utilisation of network bricolage may result in bricolage-induced inertia (Senyard et al. 2014). External stakeholders could exert considerable influence on shaping SEs' strategies in the long run, an overly risk-averse partner constraining the ability of SEs to engage in more radical changes in product and market scope.

\section{*Insert Figure 2 about here*}

Beyond establishing the relationship between the source of bricolage and its product and market orientation, our findings point to improvisation in the process of bricolage. When SEs in our sample responded to emerging opportunities or challenges over a short period of time, they had to plan concurrently with execution. Consistent with prior studies (Moorman and Miner 1998; Cunha and Kamoche 2001), improvisation plays an important role in the 
processes of new product and market development. We found that the process of product development for SEs was iterative and involved continuous modifications through learning from regular interactions with the market and their customers. This is in line with 'emergent co-shaping', highlighting the process of product development through improvisation and making do in prior studies (Garud and Karnøe 2003).

To answer the second research question, What is the role of improvisation in the process of extending product and market scope over time?, we found out not all SEs in our study use improvisation to extend their product and market scope over time. However, our study illustrates that, for those that deploy improvisation to extend their product and market scope, they tend to adopt one of the two approaches: incremental improvisation and transformative improvisation (see Figure 2). The former can be classified in two ways. One involves SEs first developing a new product or service, before, over time, expanding their market (Route a). The other involves SEs first expanding their market, before extending their product or service (Route b). In both cases, improvisation is incremental, with SEs first accomplishing either the goal of extending a product or expanding a market, before moving on to the other. Both incremental approaches enable SEs to develop a firm understanding of either the market or the product, such as related knowledge, resources and competencies, before proceeding to another. Despite not being as radical or transformative, the new product in both cases may enable SEs to develop new resources and competencies, in turn enabling them to utilise these resources and competencies to springboard onto further bricolage. SEs adopted an incremental approach due to limited resources, sensitivity of new targeted market (and fear that new products may not serve real needs), and perceived negative effect on their relationship with key stakeholders. In such cases, both incremental approaches enabled SEs to develop a firm understanding of product and market such as related knowledge, resources and competencies, before proceeding to another. Our cross-case analysis highlights that the social mission of SEs and their external partner also plays a critical role in the type of improvisation that they pursue. In the incremental improvisation both partners have a similar social mission; both of them want to serve the same market with the same product, target the same market with a new product, or focus on offering the same type of product to the new market.

A small number of SEs that adopted transformative improvisation simultaneously developed a new product for a new market (Route c). As it entailed considerable risk and uncertainty, transformative improvisation, in contrast, required external support, and an entrepreneurial mind-set. Unlike in incremental improvisation, in some cases the social 
mission of SEs' external partners dictated such an approach. For example (as in the case of local government and Homelessness Support offering housing accommodation), SEs engaged in transformative improvisation where an external partner wanted to pursue a different social mission (e.g., addressing a new product in a new market), and found the knowledge and expertise of SEs beneficial in offering the new social value. In other cases, SEs were ambitious and wanted to diversify into a totally new product and market, but lacked the required resources and competencies, and therefore sought an external partner to fill resource gaps. These SEs were able to tackle their limited resources by relying on the resources of the external network. Only when their external partner could provide resources (especially financial), were they able to simultaneously offer a new product and enter a new market. In such cases, either SEs or their partners had knowledge of the new product or market, and knew the needs of beneficiaries in that specific area. Where neither of the two partners was familiar with details of their potential clients' needs (e.g. the case of Consultancy Co. and the local council), SEs attempted to learn about those needs and develop that knowledge before offering a new product to these new customers. Finally (as in the case of Audiology Services and the NHS), SEs engaged in radical transformation only if the new initiative was in line with the social objectives of their existing key stakeholders and financial providers, or SEs could obtain their consensus.

\section{Conclusions}

Our objective was to explore the role of bricolage in the growth of product and market scope of SEs. Based on nine case studies of SEs in the UK, we show that SEs are heterogeneous in the way they use bricolage in the extension of product and market scope of their activities. Whereas SEs that rely on both internal and network bricolage are able to introduce new products and expand into new markets, those that use only internal resources first move towards either product or market development before embarking on the other through incremental improvisation. These findings contribute to the literature in two ways. First, our findings contribute to the social entrepreneurship literature and bricolage theory by delineating how internal and network bricolage can play a role in growth of SEs. More specifically, our findings show that whereas internal bricolage and network bricolage support incremental changes in product or market scope, only network bricolage enables SEs to extend both product and market scope of their activities through radical transformation. At 
the same time, however, network bricolage may be a double-edged sword, with risk-averse partners potentially constraining the direction of growth SEs can embark upon.

Second, we provide new insights on different growth routes that SEs may pursue through improvisation. In particular, our study offers an understanding of how SEs deploying internal bricolage may still achieve more far-reaching forms of growth through incremental improvisation over time. Our findings suggest that improvisation is not a static, but continuous, process that enables SEs to evolve and create new social value in their use of bricolage. At the same time, however, SEs are selective in their use of improvisation, not all adopting improvisation to achieve their growth objectives. This research also sheds light on when SEs may pursue incremental or transformative improvisation. In particular where SEs wish to test the validity of a new product, are sensitive to their clients' situation, and /or fear adversely affecting their relationship with stakeholders, SEs lean towards an incremental growth path. However, where they have an entrepreneurial mind-set, have available the support of a strong external resource network to overcome resource constraints, or obtain consensus of their existing key stakeholders to engage in a different social mission (in terms of product and market), SEs are more likely to adopt a transformative approach to bricolage and improvisation for growth.

These findings have a number of managerial and policy implications. For managers, understanding ways in which the origin of resources may impact the scope of their bricolage activities may ensure a realistic expectation of what they can achieve subject to resource constraints. This is particularly the case for SEs struggling to create immediate transformative growth without external resources or network support. As improvisation is a long-term process, SEs may consider bricolage as an incremental process and slowly move towards new products and away from their existing clientele. It is also important for managers to understand the role of external parties in the process of bricolage, in terms of creating transformative social activities and impact. This is not only with those who are known or close to them, but with anyone who can mutually benefit from collaboration.

For policy makers, an important implication is that they can play a pivotal role in providing resources to enhance the occurrence of transformative bricolage activities. A number of SEs in our study expressed a desire to be supported by the government both in terms of investigating feasibility, as well as financial and technical support for transformative activities. Policy makers may also support SEs to become better connected. A brokerage 
system based on social and networking events with government agencies, and relevant forprofit organisations, may enable SEs to better connect with external stakeholders, and enhance their ability to produce transformative change.

Our study can be extended in a number of ways, which would enhance our understanding of bricolage within social organisations. First, we selected our cases based on convenience sampling. Future studies can build on the findings of this research and test the generalizability of our findings in a larger, randomly selected population. Scholars can test the relationship of internal and network bricolage with different types of growth (in terms of product and market expansion) and the role of improvisation in different stages of growth in a larger, randomly selected population. Second, our findings are limited to SEs in the UK. Further studies on other countries, and in particular, a developing country context with a much more penurious environment, would enhance our understanding of the role of bricolage in the growth of product and market scope. Third, future studies must adopt a longitudinal approach in order to better capture the changes occurring in SEs. Fourth, this study touched upon a number of different forms of external collaboration, including donation, volunteering support, strategic alliance, resource sharing, and resource swapping, but did not quantify the nature of different external partnerships. With other parties becoming involved, goal incongruence becomes inevitable in some circumstances. For collaborations, resource dependency has a large say in how one stakeholder is related to another, and therefore further study to examine the nature of partnerships and the processes of negotiation and persuasion would enhance our understanding of the process of resource bricolage. Future studies can also examine how different forms of bricolage and improvisation impact social value creation, and hence how SEs and policy makers can prioritise the types of social activities to best embark on. Finally, this research was limited to the relationship of bricolage and growth in terms of product and market expansion. Future scholars can explore other strategies in addition to bricolage that SEs employ to achieve growth. Moreover, in this research we only focused on growth in terms of existing/new product and market expansion. Future studies could focus on different growth approaches that bricolage and improvisation may offer. 


\section{Appendix 1}

\section{Interview Guide-}

An indicative list of questions included:

1. What is your role in the organization?

2. When was your organization established?

3. Please describe the activities that your SE does. What are the products/services that you offer? What are the social problems that you address?

4. Have there been any changes in the environment over the past few years that constrain your access to resources? Please explain and give some examples.

5. Have there been any instances when you collected some resources without having any specific plan for them and then used them for a new project that came to the fore? Please give some examples.

6. Have there been any situations when you decided to pursue a project mainly because of the resources that you have in your organisation?

7. Have there been situations where you have involved several stakeholders, customers, suppliers, or other SEs to work together to tackle your resource constraints? Please give some examples.

8. Did your network ever assist you with the acquisitions of new resources (e.g. physical and financial resources, knowledge, skills that are essential to your organisation)? If so could you please elaborate further?

9. Have there been any situations when you have seen that it is not possible to plan in advance and then have designed the project while it was being implemented (e.g., in collaboration with customers, suppliers or other SEs)? Please explain and give some examples.

10. Have there been any situations when you had to change the standard ways of working in order to respond to resource limitations? Please explain and give some examples.

11. Have there been incidences where you had no idea how you were going to use the resources, but then eventually found a meaningful use which helped you to grow? Please give some examples.

12. How has the source of resources (network resources/ your own existing resources) played a role in development of products/ markets? Please provide some examples. 
13. How has growth (in terms of changes in market/product offerings) happened over the years? Please elaborate. 
References:

Anderson, Alistair R., and Sarah L. Jack. 2002. "The articulation of social capital in entrepreneurial networks: A glue or a lubricant?" Entrepreneurship \& Regional Development 14 (3):193-210. doi: 10.1080/08985620110112079.

Andreosso-O'Callaghan, B., and Helena Lenihan. 2008. "Networking: a question of firm characteristics? The case of the Shannon region in Ireland." Entrepreneurship \& Regional Development 20 (6):561-580. doi: 10.1080/08985620802462173.

Ansoff, H. Igor. 1965. Corporate Strategy: an Analytic Approach to Business Policy for Growth and Expansion. New York: McGraw-Hill.

Austin, James E., Howard Stevenson, and Jane Wei-Skillern. 2006. "Social and Commercial Entrepreneurship: Same, Different, or Both?" Entrepreneurship: Theory \& Practice 30 (1):1-22.

Baker, Ted, Anne S. Miner, and Dale T. Eesley. 2003. "Improvising firms: bricolage, account giving and improvisational competencies in the founding process." Research Policy 32 (2):255-276.

Baker, Ted, and Reed E. Nelson. 2005. "Creating Something from Nothing: Resource Construction through Entrepreneurial Bricolage." Administrative Science Quarterly 50 (3):329-366.

Batjargal, Bat. 2010. "Network dynamics and new ventures in China: A longitudinal study." Entrepreneurship \& Regional Development 22 (2):139-153. doi: 10.1080/08985620802628864.

Bowman, Edward H. 1982. "Risk Seeking by Troubled Firms." Sloan Management Review 23 (4):33-42.

Boxall, Peter, Siah Hwee Ang, and Timothy Bartram. 2011. "Analysing the 'Black Box' of HRM: Uncovering HR Goals, Mediators, and Outcomes in a Standardized Service Environment." Journal of Management Studies 48 (7):1504-1532.

Brooks, Arthur C. 2009. Social Entrepreneurship: A Modern Approach to Social Venture Creation. New Jersey: Pearson Education, Inc.

Bryman, Alan. 2008. Social Research Methods. 3rd ed. Oxford: Oxford University Press.

Bugg-Levine, Antony, Bruce Kogut, and Nalin Kulatilaka. 2012. "A New Approach to Funding Social Enterprises." Harvard Business Review 90 (1/2):118-123.

Cabinet Office. 2014. "Exposure of the voluntary, community and social enterprise sector to cuts in public funding." Cabinet Office, Office for Civil Society Accessed 05/04/2015.

https://www.gov.uk/government/uploads/system/uploads/attachment_data/file/60542/

Exposure_20of_20VCSE_20sector_20to_20public_20funding_20cuts_20FINAL.pdf.

Cabinet Office: Office of the Third Sector 2006. "Social enterprise action plan Scaling new heights." Crown Accessed 20/03/2015. http://webarchive.nationalarchives.gov.uk/20070108124358/http://cabinetoffice.gov.u k/third_sector/documents/social_enterprise/se_action_plan_\%202006.pdf.

Chabaud, Didier, Alain Fayolle, Sarah Jack, and Wadid Lamine. 2012. "Entrepreneurial Process and Social Networks: A Dynamic Perspective." Entrepreneurship \& Regional Development 24 (7/8):729-732. doi: 10.1080/08985626.2012.726508.

Chang, Sea Jin, and Unghwan Choi. 1988. "Strategy, structure and performance of korean business groups: a transactions cost approach." Journal of Industrial Economics 37 (2):141-158. 
Christensen, H. Kurt, and Cynthia A. Montgomery. 1981. "Corporate Economic Performance: Diversification Strategy Versus Market Structure." Strategic Management Journal 2 (4):327-343.

Cunha, Miguel Pina E., and Ken Kamoche. 2001. Organisational Improvisation. London: Routledge.

Dacin, M. Tina, Peter A. Dacin, and Paul Tracey. 2011. "Social Entrepreneurship: A Critique and Future Directions." Organization Science 22 (5):1203-1213. doi: 10.1287/orsc. 1100.0620.

Dacin, Peter A., M. Tina Dacin, and Margaret Matear. 2010. "Social Entrepreneurship: Why We Don't Need a New Theory and How We Move Forward From Here." Academy of Management Perspectives 24 (3):37-57. doi: 10.5465/amp.2010.52842950.

Dees, J. Gregory, Beth Battle Anderson, and Jane Wei-Skillern. 2004. "Scaling social impact." Stanford Social Innovation Review 1 (1):24-32.

Delios, Andrew, and Paul W. Beamish. 1999. "Geographic scope, product diversification and the corporate performance of Japanese firms." Strategic Management Journal 20 (8):711-727.

Denzin, Norman K. 1989. The Research Act. Englewood Cliffs, NJ: Prentice Hall.

Desa, Geoffrey. 2012. "Resource Mobilization in International Social Entrepreneurship: Bricolage as a Mechanism of Institutional Transformation." Entrepreneurship: Theory \& Practice 36 (4):727-751. doi: 10.1111/j.1540-6520.2010.00430.x.

Desa, Geoffrey, and Sandip Basu. 2013. "Optimization or Bricolage? Overcoming Resource Constraints in Global Social Entrepreneurship." Strategic Entrepreneurship Journal 7 (1):26-49.

Di Domenico, MariaLaura, Helen Haugh, and Paul Tracey. 2010. "Social Bricolage: Theorizing Social Value Creation in Social Enterprises." Entrepreneurship: Theory \& Practice 34 (4):681-703.

DTI, (Department of Trade and Industry). 2003. "A progress report on Social Enterprise: a strategy for success." Department of Trade and Industry Accessed 18/03/2015. http://www.uk.coop/sites/storage/public/downloads/strategyforsocialenterprise_progre ssreport_2003.pdf.

Duymedjian, Raffi, and Charles-Clemens Rüling. 2010. "Towards a Foundation of Bricolage in Organization and Management Theory." Organization Studies 31 (2):133-151.

Eisenhardt, Kathleen M., and Melissa E. Graebner. 2007. "Theory buidling from cases: Opportunities and challenges." Academy of Management Journal 50 (1):25-32.

Ettlie, John E., William P. Bridges, and Robert D. O'Keefe. 1984. "Organization strategy and structural differences for radical versus incremental innovation." Management Science 30 (6):682-695.

Ferneley, Elaine, and Frances Bell. 2006. "Using bricolage to integrate business and information technology innovation in SMEs." Technovation 26 (2):232-241. doi: 10.1016/j.technovation.2005.03.005.

Froelich, Karen A. 1999. "Diversification of Revenue Strategies: Evolving Resource Dependence in Nonprofit Organizations." Nonprofit and Voluntary Sector Quarterly 28 (3):246-268.

Galaskiewicz, Joseph, Wolfgang Bielefeld, and Myron Dowell. 2006. "Networks and Organizational Growth: A Study of Community Based Nonprofits." Administrative Science Quarterly 51 (3):337-380.

Garud, Raghu, and Peter Karnøe. 2003. "Bricolage versus breakthrough: Distributed and embedded agency in technology entrepreneurship." Research Policy 32 (2):277-300.

Ghauri, Pervez N., and Kjell Gronhaug. 2010. Research methods in business studies: A practical guide. 4th ed. Harlow: England: Financial Times/ Prentice Hall. 
GLA Economics. 2007. Social Enterprises in London A review of London Annual Business Survey (LABS) evidence. London, UK: Greater London Authority.

Goerzen, Anthony, and Paul W. Beamish. 2003. "Geographic scope and multinational enterprise performance." Strategic Management Journal 24 (13):1289-1306.

Graebner, Melissa E., Jeffrey A. Martin, and Philip T. Roundy. 2012. "Qualitative data: Cooking without a recipe." Strategic Organization 10 (3):276-284. doi: $10.1177 / 1476127012452821$.

Gummesson, Evert. 2003. "All research is interpretive!" Journal of Business \& Industrial Marketing 18 (6-7):482-492.

Halme, Minna, Sara Lindeman, and Paula Linna. 2012. "Innovation for Inclusive Business: Intrapreneurial Bricolage in Multinational Corporations." Journal of Management Studies 49 (4):743-784. doi: 10.1111/j.1467-6486.2012.01045.x.

Hatch, Mary Jo. 1999. "Exploring the Empty Spaces of Organizing: How Improvisational Jazz Helps Redescribe Organizational Structure." Organization Studies (Walter de Gruyter GmbH \& Co. KG.) 20 (1):75-100.

Hitt, Michael A., Robert E. Hoskisson, and Hicheon Kim. 1997. "International diversification: effects on innovation and firm performance in product-diversified firms." Academy of Management Journal 40 (4):767-798. doi: 10.2307/256948.

Hoskisson, Robert E., and Michael A. Hitt. 1990. "Antecedents and Performance Outcomes of Diversification: A Review and Critique of Theoretical Perspectives." Journal of Management 16 (2):461-509.

Hunt, J. G., Kimberly B. Boal, and Ritch L. Sorenson. 1990. "Top management leadership: Inside the black box." The Leadership Quarterly 1 (1):41-65. doi: 10.1016/10489843(90)90014-9.

Jones, Marshall B. 2007. "The Multiple Sources of Mission Drift." Nonprofit and Voluntary Sector Quarterly 36 (2):299-307.

Jones, Oswald, Allan Macpherson, and Dilani Jayawarna. 2014. Resourcing the Start-up Business: Creating Dynamic Entrepreneurial Learning Capabilities. Abingdon: Routledge.

Kickul, Jill, and Thomas S. Lyons. 2012. Understanding social entrepreneurship: The relentless pursuit of mission in an ever changing world. New York: Routledge.

King, Nigel, and Christine Horrocks. 2010. Interviews in Qualitative Research. London: Sage.

Kistruck, Geoffrey M., Christopher J. Sutter, Robert B. Lount Jr, and Brett R. Smith. 2013. "Mitigating principal-agent problems in base-of-the-pyramid markets: an identity spillover perspective." Academy of Management Journal 56 (3):659-682. doi: 10.5465/amj.2011.0336.

Lanzara, G. F. 1999. "Between transient constructs and persistent structures: designing systems in action." The Journal of Strategic Information Systems 8 (4):331-349.

Lasprogata, Gail A., and Marya N. Cotton. 2003. "Contemplating "enterprise": the business and legal challenges of social entrepreneurship." American Business Law Journal 41 (1):67-113.

Leadbeater, Charles 1997. The Rise of the Social Entrepreneur London: Demos.

Lechner, Christian, and Michael Dowling. 2003. "Firm networks: External relationships as sources for the growth and competitiveness of entrepreneurial firms." Entrepreneurship \& Regional Development 15 (1):1-26.

Levi-Strauss, Claude. 1967. The Savage Mind. Chicago: University of Chicago Press.

Lewin, Arie Y. 1998. "Introduction-Jazz Improvisation as a Metaphor for Organization Theory." Organization Science 9 (5):539-539. 
Mair, Johanna, and Ignasi Marti. 2006. "Social entrepreneurship research: A source of explanation, prediction, and delight." Journal of World Business 41 (1):36-44.

McDougall, Fred M., and David K. Round. 1984. "A Comparison of Diversifying and Nondiversifying Australian Industrial Firms." Academy of Management Journal 27 (2):384-398. doi: 10.2307/255931.

McGaughey, S. L. 2007. Narratives on Internationalisation: Legitimacy, Standards and Portfolio Entrepreneurs. Cheltenham: Edward Elgar.

Meyer, Alan, Peter J. Frost, and Karl E. Weick. 1998. "The Organization Science Jazz Festival: Improvisation as a Metaphor for Organizing-Overture." Organization Science 9 (5):540-542.

Miles, Matthew B., and A. Michael Huberman. 1994. An expanded source book qualitative data analysis. 2nd ed. Thousand Oaks: Sage Publications.

Miner, Anne S., Paula Bassoff, and Christine Moorman. 2001. "Organizational Improvisation and Learning: A Field Study." Administrative Science Quarterly 46 (2):304-337.

Montgomery, Cynthia A., and Harbir Singh. 1984. "Diversification Strategy and Systematic Risk." Strategic Management Journal 5 (2):181-191.

Moorman, Christine, and Anne S. Miner. 1998. "Organizational improvisation and organizational memory." Academy of Management Review 23 (4):698-723. doi: 10.5465/AMR.1998.1255634.

Neck, Heidi, Candida Brush, and Elaine Allen. 2009. "The landscape of social entrepreneurship." Business Horizons 52 (1):13-19.

Paton, Rob. 2003. Managing and measuring social enterprises. London: Sage Publications.

Perrini, Francesco, Clodia Vurro, and Laura A. Costanzo. 2010. "A process-based view of social entrepreneurship: From opportunity identification to scaling-up social change in the case of San Patrignano." Entrepreneurship \& Regional Development 22 (6):515-534.

Rangan, V. Kashturi, John A. Quelch, Gustavo Herrero, and Brooke Barton, eds. 2007. Business solutions for the global poor: Creating social and economic value. San Francisco: Jossey-Bass.

Robins, James, and Margarethe F. Wiersema. 1995. "A resource-based approach to the multibusiness firm: empirical analysis of portfolio interrelationships and corporate financial performance." Strategic Management Journal 16 (4):277-299.

Rumelt, Richard P. 1974. Strategy, structure, and economic performance. Boston: Harvard Business School Press.

Sarasvathy, Saras D. 2001. What makes entrepreneurs entrepreneurial? : The Darden Graduate School of Business Administration University of Virginia.

Saunders, Mark, Philip Lewis, and Adrian Thornhill. 2012. Research Methods for Business Students. 6th ed. Essex: Pearson Education.

Seelos, Christian, and Johanna Mair. 2005. "Social entrepreneurship: Creating new business models to serve the poor." Business Horizons 48 (3):241-246.

Senyard, Julienne, Ted Baker, Paul Steffens, and Per Davidsson. 2014. "Bricolage as a Path to Innovativeness for Resource $\square$ Constrained New Firms." Journal of Product Innovation Management 31 (2):211-230.

Sinkovics, Rudolf R., Penz Elfriede, and Pervez N. Ghauri. 2005. "Analysing textual data in international marketing research." Qualitative Market Research: An International Journal 8 (1):9-38.

Sirmon, David G., Michael A. Hitt, and R. Duane Ireland. 2007. "Managing firm resources in dynamic environments to create value: looking inside the black box." Academy of Management Review 32 (1):273-292. 
Smith, Brett, and Christopher Stevens. 2010. "Different types of social entrepreneurship: The role of geography and embeddedness on the measurement and scaling of social value." Entrepreneurship \& Regional Development 22 (6):575-598.

Smith, David J., and Richard K. Blundel. 2014. "Improvisation and entrepreneurial bricolage versus rationalisation." Journal of General Management 40 (1):53-78.

Stimpert, J. L., and Irene M. Duhaime. 1997. "Seeing the big picture: the influence of industry, diversification, and business strategy on performance." Academy of Management Journal 40 (3):560-583. doi: 10.2307/257053.

Suzuki, Y. 1980. "The Strategy and Structure of Top 100 Japanese Industrial Enterprises 1950 -- 1970." Strategic Management Journal 1 (3):265-291.

Thompson, John L. 2002. "The world of the social entrepreneur." The International Journal of Public Sector Management 15 (4/5):412-432.

Tracy, Sarah J. 2013. Qualitative Reseaarch Methods. 1st ed. West Sussex: Wiley-Blackwell.

Vera, Dusya, and Mary Crossan. 2004. "Theatrical improvisation: Lessons for organizations." Organization Studies 25 (5):727-749. doi: 10.1177/0170840604042412.

Voss, Glenn B., Mitzi Montoya-Weiss, and Zannie Giraud Voss. 2006. "Aligning Innovation with Market Characteristics in the Nonprofit Professional Theater Industry." Journal of Marketing Research (JMR) 43 (2):296-302.

Weick, Karl E. 1989. "Organized improvisation: 20 years of organizing." Communication Studies 40 (4):241-248.

Weick, Karl E. 1993a. "The Collapse of Sensemaking in Organizations: The Mann Gulch Disaster." Administrative Science Quarterly 38 (4):628-652.

Weick, Karl E. 1993b. "Organization redesign as improvisation." In Organizational change and redesign, edited by George P. Huber and William H. Glick., 346-382. New York: Oxford University Press.

Yin, Robert K. 2014. Case study research: Design and methods. 5th ed, Applied social research methods series. Thousand Oaks: California: Sage Publications, Inc.

Zack, Michael H. 2000. "Jazz Improvisation and Organizing: Once More from the Top." Organization Science 11 (2):227-234. 


\begin{tabular}{|c|c|c|c|c|}
\hline & $\begin{array}{l}\text { Name of the } \\
\text { social } \\
\text { enterprise* }\end{array}$ & Description of activities & $\begin{array}{l}\text { Year } \\
\text { established }\end{array}$ & $\begin{array}{ll}\text { Area of } \\
\text { operation }\end{array}$ \\
\hline 1. & The Hospice & $\begin{array}{l}\text { Supports families and cares for } \\
\text { patients (children and adults) } \\
\text { with life-limiting and life- } \\
\text { threatening conditions. }\end{array}$ & 1983 & $\begin{array}{l}\text { East of } \\
\text { England }\end{array}$ \\
\hline 2. & $\begin{array}{l}\text { Consultancy } \\
\text { Co. }\end{array}$ & $\begin{array}{l}\text { Offers a range of expertise and } \\
\text { experience in financial, } \\
\text { managerial and technical fields } \\
\text { to support organisations } \\
\text { delivering social change across } \\
\text { the UK and worldwide. }\end{array}$ & 2002 & $\begin{array}{l}\text { UK+ } \\
\text { Internationally }\end{array}$ \\
\hline 3. & $\begin{array}{l}\text { Audiology } \\
\text { Services }\end{array}$ & $\begin{array}{l}\text { Takes referrals for hearing tests } \\
\text { for adults and children and } \\
\text { discusses the results and offers } \\
\text { solutions. }\end{array}$ & 2011 & $\begin{array}{l}\text { South West of } \\
\text { England }\end{array}$ \\
\hline 4. & $\begin{array}{l}\text { Health } \\
\text { Research }\end{array}$ & $\begin{array}{l}\text { Conducts research to discover } \\
\text { vital treatments and fight } \\
\text { against diseases. }\end{array}$ & 1961 & UK \\
\hline 5. & $\begin{array}{l}\text { International } \\
\text { Aid Relief }\end{array}$ & $\begin{array}{l}\text { Helps disadvantaged people to } \\
\text { improve their lives and } \\
\text { livelihoods and have a say in } \\
\text { decisions that affect them. }\end{array}$ & 1940 & $\begin{array}{l}\text { UK+ } \\
\text { Internationally }\end{array}$ \\
\hline 6. & $\begin{array}{l}\text { Coaching } \\
\text { Service }\end{array}$ & $\begin{array}{l}\text { Offers professional } \\
\text { performance coaching and } \\
\text { mentoring service to students, } \\
\text { helping them to perform better } \\
\text { in their studies and lives. }\end{array}$ & 2013 & $\begin{array}{l}\text { North of } \\
\text { England }\end{array}$ \\
\hline 7. & $\begin{array}{l}\text { Homelessness } \\
\text { Support }\end{array}$ & $\begin{array}{l}\text { Supports homeless people with } \\
\text { a range of services including }\end{array}$ & 1987 & $\begin{array}{l}\text { South East of } \\
\text { England }\end{array}$ \\
\hline
\end{tabular}




\begin{tabular}{|c|c|c|c|c|}
\hline & & $\begin{array}{l}\text { free food, laundry, showers, } \\
\text { housing and benefits advice, } \\
\text { sleeping bags and flasks, } \\
\text { advice around finding/keeping } \\
\text { accommodation, etc. }\end{array}$ & & \\
\hline 8. & $\begin{array}{l}\text { Disadvantaged } \\
\text { Youth }\end{array}$ & $\begin{array}{l}\text { Supports young people and } \\
\text { children who may be } \\
\text { experiencing homelessness, } \\
\text { domestic violence, abuse, } \\
\text { poverty, unemployment or } \\
\text { mental health problems, etc. }\end{array}$ & 1995 & $\begin{array}{l}\text { South East of } \\
\text { England }\end{array}$ \\
\hline 9. & Empower & 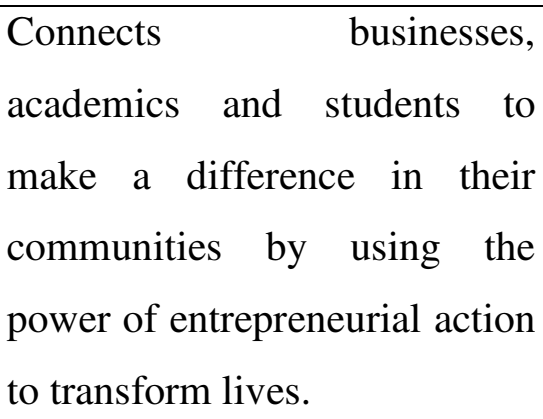 & 2001 & UK \\
\hline \multicolumn{5}{|c|}{$\begin{array}{l}\text { *Note: Fictive names have been given to the social enterprises for confidentiality } \\
\text { purposes. }\end{array}$} \\
\hline
\end{tabular}




\begin{tabular}{|l|l|l|}
\hline \multicolumn{3}{|l|}{ Table 2- An overview of the interviews } \\
\hline $\begin{array}{l}\text { Name of the social } \\
\text { enterprise }\end{array}$ & $\begin{array}{l}\text { Number } \\
\text { interviews }\end{array}$ & $\begin{array}{l}\text { Position of interviewees } \\
\text {-Director of Fundraising and } \\
\text { Marketing }\end{array}$ \\
\hline Che Hospice & 2 & Founder and CEO \\
\hline Audiology Services & 2 & $\begin{array}{l}\text { - Founder and managing director } \\
\text {-Audiologist }\end{array}$ \\
\hline Health Research & 3 & $\begin{array}{l}\text {-Warehouse manager } \\
\text {-System manager } \\
\text {-Store manager }\end{array}$ \\
\hline International Aid Relief & 2 & Shop manager \\
\hline Coaching Service & 1 & Founder and CEO \\
\hline Homelessness Support & 1 & Centre manager \\
\hline Disadvantaged Youth & 1 & Housing manager \\
\hline
\end{tabular}




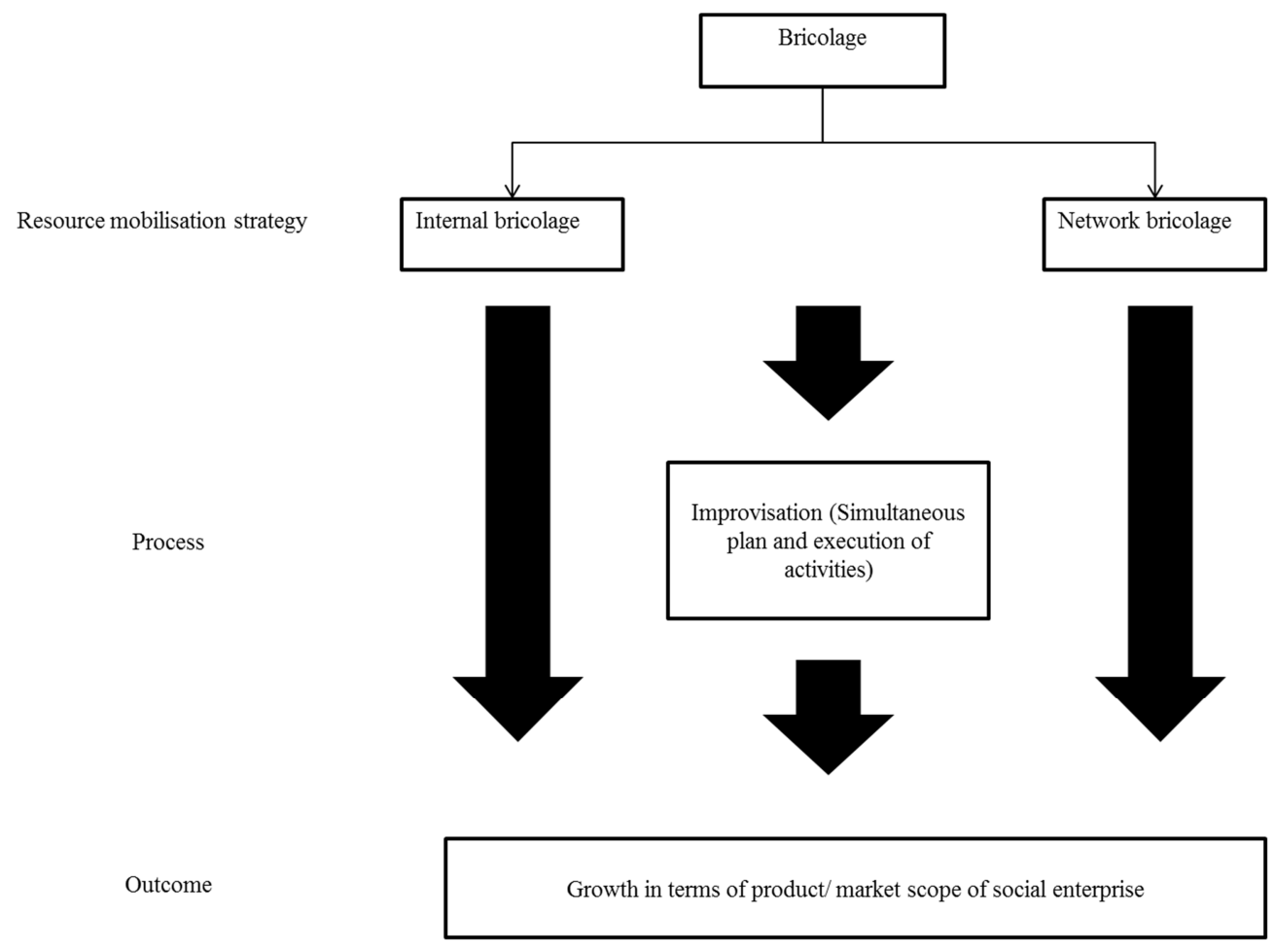

Figure 1. Conceptual framework- Bricolage, improvisation and growth in social enterprises 


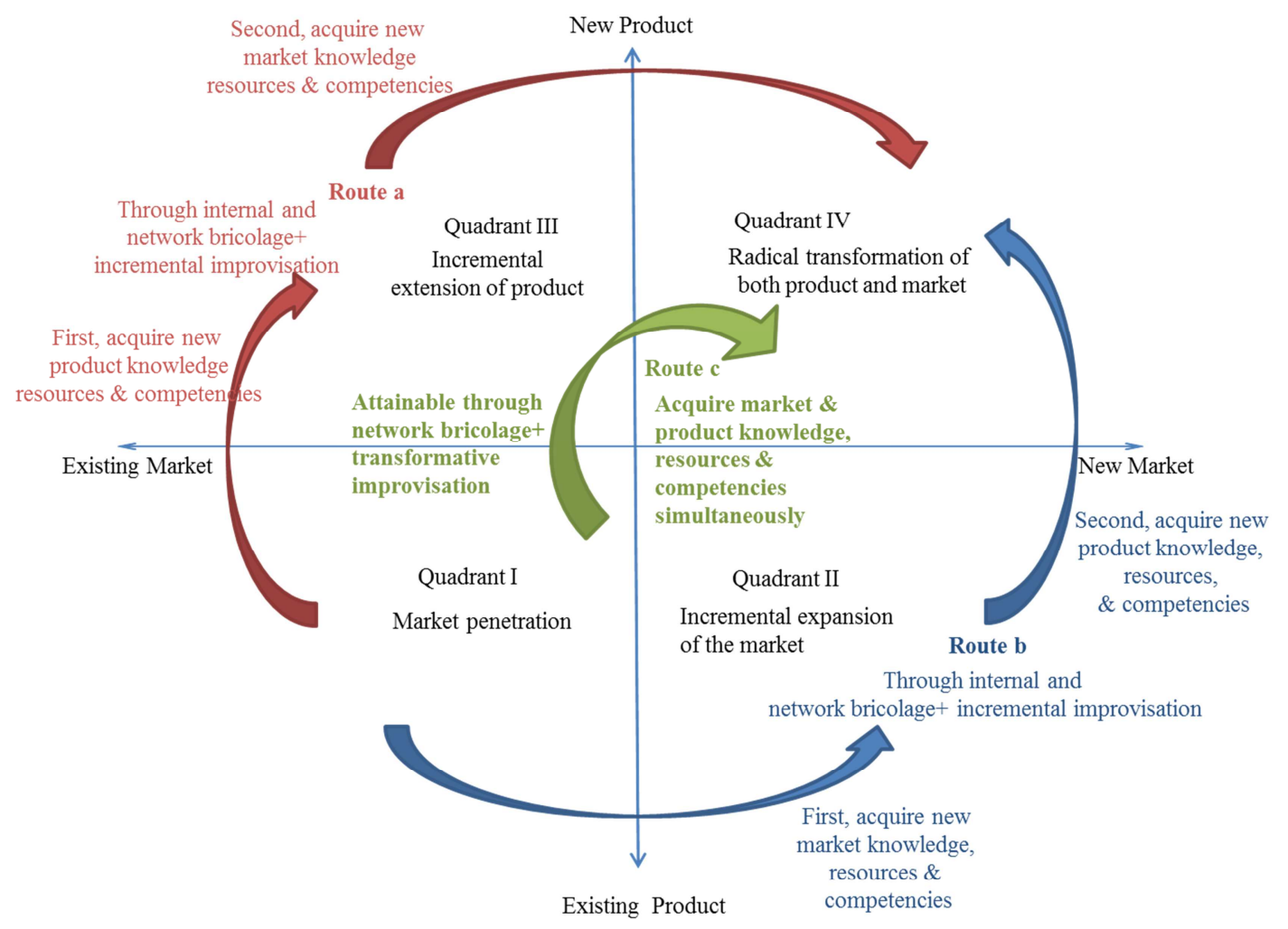

Figure 2. Bricolage, improvisation and growth through product/market scope 